\title{
Systemic inflammation in the pathogenesis of irritable bowel syndrome associated with obesity
}

Yuliya Vyacheslavivna Bilooka ${ }^{1}$, Olexander Ivanovich Fediv ${ }^{1 *}$, Hanna Yaroslavivna Stupnytska ${ }^{1}$, Vyacheslav Vasilievich Bilookyi ${ }^{2}$, Yurii Yevgenovych Rogovyi ${ }^{2}$, Michael Ivanovich Sheremet ${ }^{3}$, Valentin Nicolae Varlas ${ }^{4}$, Oleksandr Vyacheslavovich Bilookyi ${ }^{3}$

\section{Author Affiliations:}

1. Department of Internal Medicine and Infectious Diseases, Bukovinian State Medical University, Chernivtsi, Ukraine

2. Department of Pathologic Physiology, Bukovinian State Medical University, Chernivtsi, Ukraine

3. Surgery Department No.1, Bukovinian State Medical University, Chernivtsi, Ukraine

4. Department of Obstetrics and Gynaecology, Carol Davila University of Medicine and Pharmacy, Bucharest, Romania
* Corresponding Author: Olexander Ivanovich Fediv, Department of Internal Medicine and Infectious Diseases, Bukovinian State Medical University, Holovna str., 137, 58029, Chernivtsi, Ukraine. E-mail: o.fediv@gmail.com

DOI

10.25122/jml-2021-0120

\section{Dates}

Received: 14 May 2021 Accepted: 29 July 2021

\begin{abstract}
Investigation of the mechanisms promoting the development of irritable bowel syndrome (IBS) in obese patients is one of the most important issues of modern medicine. We examined 97 patients suffering from IBS. The group of comparison included 10 individuals with obesity. The control group included 21 practically healthy individuals. The levels of G-reactive protein (CRP) in the blood serum, tumor necrosis factor- $a$ (TFNa), transforming growth factor- $\beta 1$ (TGF $\beta 1$ ), interleukin-10 (IL-10), 8-isoprostane (IP), ceruloplasmin (CP) were examined. Endotoxicosis intensity was identified by the content of average molecular peptides in the blood and the Limulus Amebocyte Lysate (LAL) test. In the case of IBS with prevailing diarrhea, especially its comorbid course with obesity, cytokine imbalance was observed, which was manifested by a decreased amount of IL-10 in the blood serum and increased levels of TNFa and TGF $\beta 1$. Patients suffering from irritable bowel syndrome with prevailing diarrhea associated with obesity were characterized by high levels of C-reactive protein, fibrinogen and average molecules, increased content of pro-inflammatory cytokines (TFNa and TGF $\beta 1$ ) with a decreased content of IL-10, as well as imbalance of the pro-oxidant and anti-oxidant blood systems (increased content of 8-isoprostane and ceruloplasmin).
\end{abstract}

KEYWORDS: irritable bowel syndrome, obesity, cytokines, endotoxicosis, oxidative stress.

ABBREVIATIONS: CP - ceruloplasmin; CRP - G-reactive protein; IL-10 - interleukin-10; IP - 8-isoprostane; IBS - irritable bowel syndrome; TFNa - tumor necrosis factor-a; TGF $\beta 1$ - transforming growth factor- $\beta 1$.

\section{INTRODUCTION}

Irritable bowel syndrome (IBS) is one of the most spread functional disorders of the gastrointestinal tract, making up an important medical-social issue since it affects an individual's quality of life and social activity $[1,2]$.

A chronic course of irritable bowel syndrome, polymorphism of clinical signs, and the risk of transformation into organic pathology determine a concept of low-intensity systemic inflammation as one of the mechanisms of IBS pathogenesis [3-6]. IBS is associated with increased content of pro-inflammatory cytokines in the blood, which correlates with the severity of clinical signs of the disease and intensity of extra-intestinal symptoms [7]. 


\section{JOURNAL of MEDICINE and LIFE}

Obesity is considered as a condition of chronic subacute systemic inflammation which is associated with an increased synthesis of pro-inflammatory cytokines by both adipocytes and macrophages of the adipose tissue (interleukin (IL)- $1 \beta$, tumor necrosis factor- $\alpha$ (TFNa), CRP). Moreover, the higher the IP intensity is, the bigger the number of macrophages migrating into the adipose tissue (especially in the visceral one) is [8].

Considering the facts mentioned above, investigating the mechanisms of a comorbid course of IBS and obesity is relevant and timely. Our objective was to study systemic inflammation and oxidative stress indices in patients with IBS and associated obesity with prevailing diarrhea or constipation.

\section{MATERIAL AND METHODS}

Ninety-seven patients with IBS (37 men and 60 women aged 22 to 56 years) were examined and divided into four groups: group I - IBS with diarrhea (18 people), Group II - IBS with constipation (19 people), group III - IBS with diarrhea in combination with obesity (30 people), group IV - IBS with constipation in combination with obesity (30 people). At the same time, studies were conducted on 10 obese patients (comparison group) and 21 practically healthy individuals. Verification of the diagnosis of IBS was performed according to existing criteria [9].

The level of C-reactive protein (CRP), tumor necrosis factor- $\alpha$ (TNFa), transforming growth factor- $\beta 1$ (TGF $\beta 1$ ), interleukin-10 (IL-10), 8-isoprostane in the blood was determined by enzyme-linked immunosorbent assay (ELISA). Oxidative stress was assessed by the concentration of 8-isoprostane using ELISA. The ceruloplasmin (CP) content in the blood serum was also determined by Revin's method. The intensity of endotoxicosis was determined by the level of medium molecular peptides in the blood using the method of NI Gabrielyan and the Limulus Amebocyte Lysate (LAL) test. Statistical processing of the obtained data was performed using Biostat 2009 Professional, version 5.8.4.3 (AnalystSoft Inc.).

\section{RESULTS}

Clinical characteristics of patients are shown in Table 1.

Analysis of the level of pro-inflammatory and anti-inflammatory cytokines in the serum showed the presence of cytokine imbalance in patients with IBS and obesity, both with the predominance of diarrhea and constipation (Table 2). However, in patients with a predominance of diarrhea, we found significantly more pronounced changes, particularly a $15 \%$ lower level of IL-10. At the same time, this parameter was lower than that of practically healthy individuals by $31.6 \%, 25.1 \%, 34.8 \%$ and $23.3 \%$ in the comparison group, group I, group III and group IV, respectively. However, in group III, it was lower by $24.3 \%$ compared to group II.

Pro-inflammatory cytokines such as TNFa and TGF $\beta 1$ were significantly higher by $17.2 \%$ and $13.0 \%$ in patients of group III compared to patients of group IV, respectively. The level of TNFa was higher in obese patients (2.2 times), in patients of group I (3.6 times), in patients of group II (3.3 times), in patients of group III (4.6 times), and in patients of group IV (4.0 times) than in practically healthy individuals. The highest concentration of TGF $\beta 1$ was observed in the group of patients with IBS with diarrhea and obesity $(41.7 \%$ higher than in almost healthy individuals; $29.5 \%$ higher than in patients with diarrhea without obesity). In addition, in groups I and IV, its level was significantly higher by $15.6 \%$ and $14.6 \%$, respectively, than in group II.

Table 1. Clinical characteristic of patients.

\begin{tabular}{|c|c|c|c|c|c|c|}
\hline Parameters & PHI (control) n=21 & $\begin{array}{c}\text { Obesity (group } \\
\text { of comparison) } \\
n=10\end{array}$ & $\begin{array}{l}\text { IBS + diarrhea } \\
\text { (I group) } n=18\end{array}$ & $\begin{array}{c}\text { IBS + } \\
\text { constipation } \\
\text { (II group) } n=19\end{array}$ & $\begin{array}{l}\text { IBS + diarrhea } \\
\text { +obesity (III } \\
\text { group) } n=30\end{array}$ & $\begin{array}{c}\text { IBS + } \\
\text { constipation } \\
+ \text { obesity (IV } \\
\text { group) } n=30\end{array}$ \\
\hline Age & $32.81 \pm 1.36$ & $32.00 \pm 2.19$ & $38.56 \pm 2.59$ & $35.56 \pm 2.27$ & $35.53 \pm 1.81$ & $34.2 \pm 1.89$ \\
\hline Sex & $14 / 7$ & $7 / 3$ & $12 / 6$ & $11 / 8$ & $18 / 12$ & 19/11 \\
\hline BMI & $22.19 \pm 0.37$ & $31.1 \pm 1.04$ & $22.28 \pm 0.53$ & $24.56 \pm 0.64$ & $32.10 \pm 0.37$ & $32.10 \pm 0.33$ \\
\hline $\begin{array}{l}\text { Duration of the } \\
\text { disease }\end{array}$ & - & $5.1 \pm 0.99$ & $4.94 \pm 0.36$ & $4.78 \pm 0.38$ & $5.07 \pm 0.32$ & $4.87 \pm 0.34$ \\
\hline
\end{tabular}

BMI - body mass index; IBS - irritable bowel syndrome; PHI - practically healthy individuals. 


\begin{tabular}{|c|c|c|c|c|c|c|}
\hline Parameters & PHI (control) n=21 & $\begin{array}{c}\text { Obesity (group } \\
\text { of comparison) } \\
n=10\end{array}$ & $\begin{array}{l}\text { IBS with diarrhea } \\
\text { (I group) } n=18\end{array}$ & $\begin{array}{c}\text { IBS with } \\
\text { constipation } \\
\mathrm{n}=19 \text { (II group) }\end{array}$ & $\begin{array}{c}\text { IBS with } \\
\text { diarrhea. Obesity } \\
\text { (III group) } n=30\end{array}$ & $\begin{array}{c}\text { IBS with } \\
\text { constipation } \\
+ \text { obesity (IV } \\
\text { group) } n=30\end{array}$ \\
\hline IL-10. & $9.90 \pm 0.59$ & $\begin{array}{l}6.77 \pm 0.31 \\
p<0.05\end{array}$ & $\begin{array}{l}7.42 \pm 0.37 \\
p<0.05 \\
p_{1}>0.05\end{array}$ & $\begin{array}{c}8.59 \pm 0.29 \\
p>0.05 \\
p_{1}>0.05 \\
p_{2}>0.05\end{array}$ & $\begin{array}{c}6.45 \pm 0.25 \\
p<0.05 \\
p_{1}>0.05 \\
p_{2}>0.05 \\
p_{3}<0.05\end{array}$ & $\begin{array}{c}7.59 \pm 0.36 \\
\mathrm{p}<0.05 \\
\mathrm{p}_{1}>0.05 \\
\mathrm{p}_{2}>0.05 \\
\mathrm{p}_{3}>0.05 \\
\mathrm{p}_{4}<0.05\end{array}$ \\
\hline TNF $\alpha$. & $7.57 \pm 0.19$ & $\begin{array}{c}16.98 \pm 1.80 \\
p<0.05\end{array}$ & $\begin{array}{c}27.23 \pm 1.03 \\
p^{2}<0.05 \\
p_{1}<0.05\end{array}$ & $\begin{array}{c}24.73 \pm 1.11 \\
p<0.05 \\
p_{1}<0.05 \\
p_{2}>0.05\end{array}$ & $\begin{array}{c}35.11 \pm 1.26 \\
\mathrm{p}<0.05 \\
\mathrm{p}_{1}<0.05 \\
\mathrm{p}_{2}<0.05 \\
\mathrm{p}_{3}<0.05\end{array}$ & $\begin{array}{c}29.97 \pm 1.08 \\
\mathrm{p}_{1}<0.05 \\
\mathrm{p}_{1}<0.05 \\
\mathrm{p}_{2}>0.05 \\
\mathrm{p}_{3}<0.05 \\
\mathrm{p}_{4}<0.05\end{array}$ \\
\hline $\begin{array}{l}\text { TGF } \beta 1 . \\
\mathrm{pg} / \mathrm{ml}\end{array}$ & $33.37 \pm 0.43$ & $\begin{array}{c}37.58 \pm 0.86 \\
p<0.05\end{array}$ & $\begin{array}{c}43.27 \pm 0.76 \\
p^{2}<0.05 \\
p_{1}<0.05\end{array}$ & $\begin{array}{c}36.51 \pm 0.67 \\
\mathrm{p}<0.05 \\
\mathrm{p}_{1}>0.05 \\
\mathrm{p}_{2}<0.05\end{array}$ & $\begin{array}{c}47.28 \pm 1.02 \\
p_{2}<0.05 \\
p_{1}<0.05 \\
p_{2}<0.05 \\
p_{3}<0.05\end{array}$ & $\begin{array}{c}41.85 \pm 0.77 \\
\mathrm{p}<0.05 \\
\mathrm{p}_{1}<0.05 \\
\mathrm{p}_{2}>0.05 \\
\mathrm{p}_{3}<0.05 \\
\mathrm{p}_{4}<0.05\end{array}$ \\
\hline $\begin{array}{l}\text { CRP. } \\
\mathrm{mg} / \mathrm{l}\end{array}$ & $3.67 \pm 0.38$ & $\begin{array}{c}7.10 \pm 0.90 \\
p>0.05\end{array}$ & $\begin{array}{l}11.56 \pm 1.36 \\
p<0.05 \\
p_{1}<0.05\end{array}$ & $\begin{array}{c}7.53 \pm 0.76 \\
p<0.05 \\
p_{1}>0.05 \\
p_{2}<0.05\end{array}$ & $\begin{array}{c}14.00 \pm 1.08 \\
\mathrm{p}<0.05 \\
\mathrm{p}_{1}<0.05 \\
\mathrm{p}_{2}>0.05 \\
\mathrm{p}_{3}<0.05\end{array}$ & $\begin{array}{c}9.19 \pm 0.90 \\
\mathrm{p}<0.05 \\
\mathrm{p}_{1}>0.05 \\
\mathrm{p}_{2}>0.05 \\
\mathrm{p}_{3}>0.05 \\
\mathrm{p}_{4}<0.05\end{array}$ \\
\hline $\begin{array}{l}\text { Fibrinogen. } \\
\text { g/l }\end{array}$ & $3.30 \pm 0.09$ & $\begin{array}{c}4.39 \pm 0.16 \\
p<0.05\end{array}$ & $\begin{array}{l}4.33 \pm 0.16 \\
p<0.05 \\
p_{1}>0.05\end{array}$ & $\begin{array}{c}3.59 \pm 0.27 \\
\mathrm{p}>0.05 \\
\mathrm{p}_{1}>0.05 \\
\mathrm{p}_{2}>0.05\end{array}$ & $\begin{array}{c}4.61 \pm 0.26 \\
\mathrm{p}<0.05 \\
\mathrm{p}_{1}>0.05 \\
\mathrm{p}_{2}<0.05\end{array}$ & $\begin{array}{c}3.47 \pm 0.19 \\
\mathrm{p}_{2}<0.05 \\
\mathrm{p}_{1}<0.05 \\
\mathrm{p}_{2}<0.05 \\
\mathrm{p}_{3}>0.05 \\
\mathrm{p}_{4}<0.05\end{array}$ \\
\hline $\begin{array}{l}\text { 8-isoprostan. } \\
\mathrm{ng} / \mathrm{ml}\end{array}$ & $1.29 \pm 0.02$ & $\begin{array}{l}1.46 \pm 0.07 \\
p>0.05\end{array}$ & $\begin{array}{c}2.01 \pm 0.09 \\
p<0.05 \\
p_{1}<0.05\end{array}$ & $\begin{array}{c}1.51 \pm 0.04 \\
\mathrm{p}>0.05 \\
\mathrm{p}_{1}>0.05 \\
\mathrm{p}_{2}<0.05\end{array}$ & $\begin{array}{c}2.30 \pm 0.09 \\
p<0.05 \\
p_{1}<0.05 \\
p_{2}<0.05 \\
p_{3}<0.05\end{array}$ & $\begin{array}{c}1.64 \pm 0.06 \\
\mathrm{p}<0.05 \\
\mathrm{p}_{1}>0.05 \\
\mathrm{p}_{2}<0.05 \\
\mathrm{p}_{3}>0.05 \\
\mathrm{p}_{4}<0.05\end{array}$ \\
\hline $\begin{array}{l}\text { Ceruloplasmin. } \\
\mathrm{mg} / \mathrm{l}\end{array}$ & $0.92 \pm 0.02$ & $\begin{array}{l}1.33 \pm 0.11 \\
p<0.05\end{array}$ & $\begin{array}{l}1.89 \pm 0.08 \\
p<0.05 \\
p_{1}<0.05\end{array}$ & $\begin{array}{c}1.61 \pm 0.08 \\
\mathrm{p}<0.05 \\
\mathrm{p}_{1}>0.05 \\
\mathrm{p}_{2}<0.05\end{array}$ & $\begin{array}{c}2.02 \pm 0.07 \\
\mathrm{p}<0.05 \\
\mathrm{p}_{1}<0.05 \\
\mathrm{p}_{2}>0.05 \\
\mathrm{p}_{3}<0.05\end{array}$ & $\begin{array}{c}1.64 \pm 0.06 \\
\mathrm{p}_{1}<0.05 \\
\mathrm{p}_{1}<0.05 \\
\mathrm{p}_{2}<0.05 \\
\mathrm{p}_{3}>0.05 \\
\mathrm{p}_{4}<0.05\end{array}$ \\
\hline $\begin{array}{l}\text { Average } \\
\text { molecules. }\end{array}$ & $0.234 \pm 0.002$ & $\begin{array}{c}0.249 \pm 0.004 \\
p<0.05\end{array}$ & $\begin{array}{c}0.250 \pm 0.005 \\
p<0.05 \\
p_{1}>0.05\end{array}$ & $\begin{array}{c}0.244 \pm 0.002 \\
p<0.05 \\
p_{1}>0.05 \\
p_{2}>0.05\end{array}$ & $\begin{array}{c}0.257 \pm 0.015 \\
\mathrm{p}<0.05 \\
\mathrm{p}_{1}>0.05 \\
\mathrm{p}_{2}>0.05 \\
\mathrm{p}_{3}<0.05\end{array}$ & $\begin{array}{c}0.248 \pm 0.002 \\
p_{1}<0.05 \\
p_{1}>0.05 \\
p_{2}>0.05 \\
p_{3}>0.05 \\
p_{4}<0.05\end{array}$ \\
\hline
\end{tabular}

BMI - body mass index; CRP - C-reactive protein; IBS - irritable bowel syndrome; IL-10 - interleukin-10; TGF $\beta 1$ - transforming growth factor- $\beta 1$; TNF- $\alpha$ - tumor necrosis factor- $\alpha$. 


\section{JOURNAL of MEDICINE and LIFE}

The level of CRP was higher than in practically healthy individuals: 3.1 times in group I, 2.1 times in group II, 3.8 times in group III, and 2.5 times in group IV. It was found that in group I, it was $34.9 \%$ higher than in the presence of constipation; in group III, it was higher by $24.7 \%$ and $52.3 \%$ than in groups II and IV, respectively. The fibrinogen content in cases of obesity, IBS with diarrhea, IBS with obesity and diarrhea exceeded the corresponding values in almost healthy individuals by $33.0 \%, 31.2 \%$, and $39.7 \%$, respectively. In patients of group III, it was $28.4 \%$ higher than in group I and $32.9 \%$ higher than in group IV.

When studying the primary marker of oxidative stress, namely 8-isoprostane, it was found that its level in the serum of patients of group III was 1.8 times higher than control, 1.6 times than the comparison group; $14.4 \%$ - group I, 1.5 times - group II and $40.2 \%$ - group IV. In groups I and IV of patients, its value was also higher than the control group by $55.8 \%$ and $27.1 \%$, respectively. In patients with IBS without obesity, the content of 8 -isoprostane was higher in group I compared with group II (by $24.9 \%$ ).

The level of ceruloplasmin was also higher in group III patients (2.2 times compared with the group of practically healthy individuals, $51.9 \%$ compared with obese patients, $25.5 \%$ compared with group II and 23.2\% compared with group IV). In obese patients, it was 44.6\% higher, in group I, it was 2.1 times higher, in groups II and IV 1.8 times higher than in PZO. With the benefits of diarrhea, the ceruloplasmin level was $17.4 \%$ higher than with the benefits of constipation.

When studying the rate of endogenous intoxication, namely the content of medium molecules in blood plasma, a similar trend with ceruloplasmin was found; however, it was less pronounced.

Thus, in IBS with diarrhea, especially in its comorbid course with obesity, there is an imbalance of cytokines, which was manifested through a reduced content of IL-10 with increasing levels of TNFa and TGF $\beta 1$.

The results of our study correlate with the data indicating that in the case of IBS, especially with diarrhea, cytokine imbalance occurs by an increase of pro-inflammatory and decrease of anti-inflammatory ones [10]. Many other pieces of research demonstrated the role of cytokines in IBS pathogenesis and their association with the manifestation of clinical signs [11, 12]. IBS is known to be a multi-factorial disease. It was associated with functional disorders only before. However, the participation of the immune system and the development of low-grade chronic inflammatory syndrome with this pathology has been evidenced. The role of systemic inflammation with obesity, especially with its abdominal type, is aslo demonstrated [13, 14].

\section{DISCUSSION}

Thus, it could be suggested that IBS with prevailing diarrhea stipulates inflammatory changes not only in the intestines but at the systemic level, and comorbid obesity intensifies the chronic systemic inflammatory process. We found out that patients with IBS, prevailing diarrhea and comorbid obesity develop a higher intensity of systemic inflammation, which was characterized by a high level of CRP in the blood serum and fibrinogen level. Oxidative stress is confirmed to be one of the main parts of pathogenesis in the case of many diseases, including gastrointestinal pathology [15-21]. Numerous studies demonstrated an imbalance of the pro- and antioxidant blood systems with chronic gastrointestinal tract diseases and IBS in particular [22-27].

Thus, we found an imbalance of the pro- and antioxidant blood system in IBS with diarrhea and obesity, as evidenced by high levels of 8-isoprostane and ceruloplasmin. The level of medium molecules in the blood plasma showed that the level of endogenous intoxication is more pronounced in IBS with diarrhea and obesity.

\section{CONCLUSION}

Patients with irritable bowel syndrome with diarrhea and obesity are characterized by an increased content of C-reactive protein, fibrinogen, and medium molecules, pro-inflammatory cytokines (TNFa and TGF $\beta 1$ ) with a decreased content of IL-10, as well as an imbalance of prooxidant and antioxidant systems (an increased content of 8-isoprostane and ceruloplasmin).

\section{ACKNOWLEDGMENTS}

\section{Ethical approval}

The approval for this study was obtained from the Ethics Committee of the Bukovinian State Medical University and Chernivtsi Regional Hospital, Ukraine (approval ID: 11-02/11/2019).

\section{Consent to participate}

The participants gave written informed consent for participation in this study. 


\section{Conflict of interest}

The authors declare that there is no conflict of interest.

\section{REFERENCES}

1. Khanijow V, Prakash P, Emsellem HA, Borum MI, Doman DB. Sleep Dysfunction and Gastrointestinal Diseases. Gastroenterol Hepatol (N Y). 2015 Dec;11(12):817-25.

2. Popa SL, Dumitrascu DL. Anxiety and IBS revisited: ten years later. Clujul Med. 2015;88(3):253-7.

3. Barbaro MR, Di Sabatino A, Cremon C, Giuffrida P, Fiorentino M, Altimari A, Bellacosa L, Stanghellini V, Barbara G. Interferon- $\gamma$ is increased in the gut of patients with irritable bowel syndromeand modulates serotonin metabolism. Am J Physiol Gastrointest Liver Physiol. 2016 Mar 15;310(6): G439-47.

4. Bennet SM, Polster A, Törnblom H, Isaksson S, Capronnier S, Tessier A, Le Nevé B, Simrén M, Öhman L. Global Cytokine Profi les and Association With Clinica Characteristics in Patients With Irritable Bowel Syndrome. Am J Gastroenterol. 2016 Aug;111(8):1165-76.

5. Jonefj äll B, Öhman L, Simrén M, Strid H. IBS-like Symptoms in Patients with Ulcerative Colitis in Deep Remission Are Associated with Increased Levels of Serum Cytokines and Poor Psychological Well-being. Infl amm Bowel Dis. 2016 Nov; 22(11):2630-2640.

6. Pike BL, Paden KA, Alcala AN, Jaep KM, Gormley RP Maue AC, Christmann BS, Elson CO, Riddle MS, Porter CK. Immunological Biomarkers in Postinfectious Irritable Bowel Syndrome J Travel Med. 2015 JulAug;22(4):242-50.

7. Zhen Y, Chu C, Zhou S, Qi M, Shu R. Imbalance of tumor necrosis factor- $\mathrm{a}$, interleukin-8 and interleukin-10 productiones production irritable bowel syndrome-associated diarrhea. Mol Med Rep. 2015 Oct; $12(4): 5239-45$.

8. Tchernot A, Despers JP. Pathophysiology of human visceral obesity: an update. Physiol. Rev. 2013; 93(1): 359-404.

9. Ford AC, Bercik P, Morgan DG. et al. Validation of the Rome III criteria for the diagnosis of irritable bowel syndrome in secondary care. Gastroenterology. 2013; 145(6): 1262-1270.

10. Babaeva AR, Osadchuk MA, Vidiker RV, Kalinina EV, Solodenkova KS. Markers of systemic inflammation in pathogenesis and optimization of pharmacotherapy of irritable bowel syndrome. Experimental and Clinical Gastroenterology. 2017; 139 (3): 48-55.

11. Kristen R Weaver, Christina M Boulineaux, Jeffrey M Robinson, Kierra Butler, Margaret M Heitkemper, Wendy A Robinson, Kierra Butler, Margaret M Heitkemper, Wendy $A$ Henderson. Sex Hormones, BDNF, Leptin, and TGF- $\beta 1$
Females With IBS: A Pilot Investigation. Biol Res Nurs. 2021 Apr;23(2): 231-237.

12. An S, Zong G, Wang Z, Shi J, Du H, Hu J. Expression of inducible nitric oxide synthase in mast cells contributes to the regulation of inflammatory cytokines in irritable bowel syndrome with diarrhea. Neurogastroenterol Motil. $2016 \mathrm{Jul} ; 28(7): 1083-93$.

13. Wu H, Ballantyne CM. Metabolic Inflammation and Insulin Resistance in Obesity. Circ Res. 2020 May 22;126(11):1549-1564

14. Kawai T, Autieri MV, Scalia R. Adipose tissue inflammation and metabolic dysfunction in obesity. Am J Physiol Cell Physiol. 2021 Mar 1;320(3):C375-C391.

15. Pereira C, Grácio D, Teixeira JP, Magro F. Oxidative Stress and DNA Damage: Implications in Inflammatory Bowel Disease. Inflamm Bowel Dis. 2015 Oct;21(10):2403-17.

16. Korolczuk A, Caban K, Amarowicz M, Czechowska G, Irla-Miduch J. Oxidative Stress and Liver Morphology in Experimental Cyclosporine A-Induced Hepatotoxicity. Biomed Res Int. 2016;2016:5823271.

17. Gonzalez-Paredes FJ, Hernández Mesa G, Morales Arraez D, Marcelino Reyes R, Abrante B, Diaz-Flores F, Salido E, Quintero E, Hernández-Guerra M. Contribution of Cyclooxygenase End Products and Oxidative Stress to Intrahepatic Endothelial Dysfunction in Early Non-Alcoholic Fatty Liver Disease. PLoS One. 2016 May 26;11(5):e0156650.

18. Wang X, Hausding M, Weng SY, Kim YO, Steven S, Klein T, Daiber A, Schuppan D. Gliptins Suppress Inflammatory Macrophage Activation to Mitigate Inflammation, Fibrosis, Oxidative Stress, and Vascular Dysfunction in Models of Oxidative Stress, and Vascular Dysfunction in Models of
Nonalcoholic Steatohepatitis and Liver Fibrosis. Antioxid Redox Signal. 2018 Jan 10;28(2):87-109.

19. Kattoor AJ, Pothineni NVK, Palagiri D, Mehta JL. Oxidative Stress in Atherosclerosis. Curr Atheroscler Rep. 2017 Sep 18;19(11):42.
20. Senoner T, Dichtl W.Nutrients. Oxidative Stress in Cardiovascular Diseases: Still a Therapeutic Target? 2019 Sep 4;11(9):2090.

21. Jadeja RN, Devkar RV, Nammi S. Oxidative Stress in Liver Diseases: Pathogenesis, Prevention, and Therapeutics. Liver Diseases: Pathogenesis, Prevention, and
Oxid Med Cell Longev. 2017;2017:8341286. doi: 10.1155/2017/8341286. Epub 2017 Apr 25.

22. Balmus IM, Ciobica A, Cojocariu R, Luca AC, Gorgan L. Irritable Bowel Syndrome and Neurological Deficiencies: Is There A Relationship? The Possible Relevance of the Oxidative Stress Status. Medicina (Kaunas). 2020 Apr 13;56(4):175.

23. Balmus IM, Ilie OD, Ciobica A, Cojocariu RO, Stanciu C, Trifan A, Cimpeanu M, Cimpeanu C, Gorgan L. Irritable Bowel Syndrome between Molecular Approach and Clinical Expertise-Searching for Gap Fillers in the Oxidative Stress Way of Thinking. Medicina (Kaunas). 2020 Jan 19;56(1):38

24. Choghakhori R, Abbasnezhad A, Hasanvand A, Amani R. Inflammatory cytokines and oxidative stress biomarkers in irritable bowel syndrome: Association with digestive symptoms and quality of life. Cytokine. 2017 May;93:34-43.

25. Cojocariu RO, Balmus IM, Lefter R, Hritcu L, Ababei DC, Ciobica A, Copaci S, Mot SEL, Copolovici L, Copolovici DM, Jurcoane S. Camelina sativa Methanolic and Ethanolic Extract Potential in Alleviating Oxidative Stress, Memory Deficits, and Affective Impairments in Stress Exposure-Based Irritable Bowel Syndrome Mouse Models. Oxid Med Cell Longev. 2020 Dec 23;2020:9510305.

26. Cojocariu RO, Balmus IM, Lefter R, Ababei DC, Ciobica A, Hritcu L, Kamal F, Doroftei B. Behavioral and Oxidative Stress Changes in Mice Subjected to Combinations of Multiple Stressors Relevant to Irritable Bowel Syndrome. Brain Sci. 2020 Nov 17;10(11):865.

27. Balmus IM, Cojocariu RO, Ciobica A, Strungaru S, Strungaru-Jijie R, Cantemir A, Galatanu C, Gorgan L. Preliminary Study on the Tears Oxidative Stress Status and Sleep Disturbances in Irritable Bowel Syndrome Patient Oxid Med Cell Longev. 2020 May 23;2020:4690713. 